\title{
PENEKANAN PERKEMBANGAN PENYAKIT BUSUK BATANG VANILI (FUSARIUM OXYSPORUM F.SP. VANILLAE) MELALUI SELEKSI ASAM FUSARAT SECARA IN VITRO
}

\author{
Endang Nurcahyani ${ }^{1}$, Issirep Sumardi ${ }^{2}$, Bambang Hadisutrisno ${ }^{3}$ \& E. Suharyanto ${ }^{2}$ \\ ${ }^{1} J u r u s a n$ Biologi, Fakultas Matematika dan Ilmu Pengetahuan Alam, Universitas Lampung \\ Email: endang_nurcahyani@yahoo.com \\ ${ }^{2}$ Jurusan Botani, Laboratorium Struktur dan Perkembangan Tumbuhan, \\ Fakultas Biologi, Universitas Gadjah Mada \\ ${ }^{3}$ Jurusan Perlindungan Tanaman, Fakultas Pertanian, Universitas Gadjah Mada
}

\begin{abstract}
Suppression of development of vanilla foot rot disease (Fusarium oxysporum $f$.sp. vanillae) through in vitro fusaric acid selection. The most biological constrain on Vanilla planifolia plantation recently was caused by epidemical disease that later decrease vanilla production. The most important disease on vanilla is foot rot disease caused by Fusarium oxysporum f. sp. vanillae. So far, the disease has not been successfully controlled although some experiments had been conducted. One alternative method has been introduced by using a new cultivar which was resistance to Fusarium). A mutant vanilla to the fungus has been initiated by in vitro selection on medium containing fusaric acid. The aims of this research were: (1) to investigate effective concentration of fusaric acid used for in vitro selection, (2) to characterize mutants which have been set up and also to test those mutants for their resistance to the fungus. The results showed that: (1) fusaric acid at the concentration of $110 \mathrm{ppm}$ effectively suppressed the disease intensity up to $25 \%$ compared to the concentration of $90 \mathrm{ppm}$ and $100 \mathrm{ppm}$. In other words, $110 \mathrm{ppm}$ of fusaric acid has increased the category criterion from moderate to resistant, (2) there was an increase of the total phenol content and thickness of lignin in vanilla stem, and (3) the protein profile of vanilla plantlet was different from the control. There was an initiation of a new band of about $18 \mathrm{kD}$ in a mutant predicted as a protein which is responsible for vanilla resistance to Fusarium.
\end{abstract}

Key words: the vanilla foot rot disease, Fusarium oxysporum f.sp. vanillae, fusaric acid

\section{ABSTRAK}

Penekanan perkembangan penyakit busuk batang vanili (Fusarium oxysporum $f$.sp. vanillae) melalui seleksi asam fusarat secara in vitro. Kendala biologi dalam budidaya vanili (Vanilla planifolia Andrews) akhir-akhir ini adalah epidemi penyakit busuk batang yang mengakibatkan turunnya produksi. Penyakit busuk batang, yang disebabkan oleh jamur Fusarium oxysporum f. sp. vanillae sampai saat ini masih belum bisa diatasi secara efektif walaupun beberapa penelitian telah dilakukan. Penggunaan kultivar vanili yang tahan penyakit busuk batang dengan hasil tinggi merupakan alternatif pengendalian penyakit yang penting. Mutan yang resisten terhadap infeksi $F$. oxysporum f. sp. vanillae telah diinisiasi dan diseleksi secara in vitro dalam medium MS dengan penambahan asam fusarat. Tujuan penelitian ini adalah: (1) mengetahui konsentrasi asam fusarat yang efektif untuk menekan jamur $F$. oxysporum f.sp. vanillae dan mengkaji tingkat resistensi planlet vanili yang digunakan pada seleksi in vitro, dan (2) mengetahui dan mengkaji karakter mutan vanili resisten penyakit busuk batang. Hasil penelitian menunjukkan bahwa (1) penekanan jamur $F$ oxysporum f.sp. vanillae menggunakan asam fusarat konsentrasi $110 \mathrm{ppm}$ lebih efektif dibandingkan dengan konsentrasi 90 dan 100 ppm dan mampu menekan intensitas penyakit hingga $25 \%$ serta meningkatkan kriteria ketahanan dari moderat ke tahan, (2) terdapat peningkatan kandungan total fenol dan ketebalan lignin pada vanili resisten penyakit busuk batang, dan (3) profil protein daun planlet vanili resisten penyakit busuk batang berbeda dengan kontrol. Ada inisiasi pita baru $\pm 18 \mathrm{kD}$ yang diduga sebagai protein yang bertanggung jawab pada resistensi $F$. oxysporum f. sp. vanillae.

Kata kunci: penyakit busuk batang vanili, Fusarium oxysporum f.sp. vanillae, asam fusarat

\section{PENDAHULUAN}

Vanili (Vanilla planifolia Andrews) merupakan salah satu tanaman industri yang mempunyai nilai ekonomi tinggi sebagai komoditas ekspor penghasil devisa yang masih potensial dikembangkan di Indonesia. Di pasaran internasional, vanili Indonesia dikenal dengan sebutan Java Vanilla Beans karena mempunyai kualitas 
terbaik dengan kadar vanillin 2,75\% (Hadisutrisno, 2004). Hal tersebut menjadi modal dasar bagi Indonesia untuk terus memperluas pasaran ekspor, guna meningkatkan penerimaan devisa negara serta meningkatkan pendapatan petani. Peluang pasar komoditas vanili Indonesia masih terbuka luas karena dengan bertambahnya jumlah penduduk dunia, permintaan vanili diperkirakan terus meningkat (Pusat Data dan Informasi Pertanian, 2009). Namun demikian permintaan vanili yang tinggi tersebut tidak diimbangi dengan tingkat produktivitas yang memadai karena adanya beberapa kendala dalam pengembangan vanili di Indonesia.

Salah satu penyakit utama yang menjadi kendala dalam budidaya vanili adalah penyakit busuk batang, yang disebabkan oleh jamur Fusarium oxysporum f.sp. vanillae. Penyakit ini menyebabkan kerugian yang sangat besar akibat matinya tanaman $(50 \%-100 \%)$, memperpendek umur produksi dari 10 kali panen menjadi dua kali, bahkan tidak dapat berproduksi, serta mutu buah sangat rendah (Hadisutrisno, 2004). Sampai saat ini penyakit busuk batang vanili telah diteliti oleh beberapa laboratorium (Lestari et.al., 2006; Inayati, 2002) tetapi masih belum bisa diatasi secara efektif.

Penggunaan kultivar unggul yang tahan terhadap penyakit busuk batang dengan daya hasil tinggi merupakan salah satu alternatif pengendalian penyakit yang penting dan tidak menimbulkan dampak negatif seperti penggunaan fungisida. Mutan atau kultivar yang resisten terhadap infeksi $F$. oxysporum dapat diidentifikasi melalui seleksi secara in vitro dalam media dengan penambahan asam fusarat (Bacon et al., 1996). Asam fusarat (5-n-butylpicolinic acid) merupakan fitotoksin non-spesifik yang dihasilkan oleh $F$. oxysporum yang menyebabkan gejala layu serta busuk pada berbagai tanaman (Remotti \& Löfter, 1996; Toyoda et al., 1988 cit. Landa et al., 2002). Selain itu asam ini dapat menyebabkan klorosis pada daun muda, bersifat toksin yang berperan menghambat oksidasi sitokinin, menghambat proses respirasi pada mitokondria, menurunkan adenosin three posphat (ATP) pada plasma membran serta mereduksi aktivitas polifenol oksidasi sehingga menghambat pertumbuhan dan regenerasi biakan (Sukmadjaja et al., 2003). Namun ada korelasi positif antara ketahanan plantlet terhadap toksin dengan ketahanan tanaman terhadap Fusarium (Arai \& Takeuchi, 1993). Bouizgarne et al. (2006) menyatakan konsentrasi asam fusarat toksik menyebabkan kematian tanaman, tetapi konsentrasi non toksik (di bawah $10^{-6}$ M) justru membantu mengimbas sintesis fitoaleksin, suatu bentuk respon tanaman untuk menghambat aktivitas patogen. Penggunaan asam fusarat sebagai agen penyeleksi dalam seleksi in vitro dapat menghasilkan sel atau jaringan mutan yang insensitif terhadap asam fusarat, sehingga setelah diregenerasikan menjadi tanaman dapat menghasilkan galur yang resisten atau toleran terhadap infeksi patogen. Metode ini telah dilakukan antara lain pada tanaman tomat (Toyoda et al., 1984), pisang (Matsumoto et al., 1995), gladiol (Remotti et al., 1997), dan nanas (Borras et al., 2001), menunjukkan ketahanannya terhadap penyakit layu Fusarium.

Sejauh ini masalah penyakit busuk batang vanili belum bisa diatasi secara efektif dan belum ada kultivar unggul vanili yang tahan terhadap Fusarium oxysporum f.sp. vanillae penyebab penyakit busuk batang. Oleh karena itu, perlu dilakukan penelitian penekanan jamur F. oxysporum f.sp. vanillae melalui seleksi dengan asam fusarat secara in vitro. Dari penelitian ini diharapkan diperoleh kultivar atau mutan vanili tahan penyakit busuk batang yang selanjutnya akan dapat meningkatkan kembali mutu dan produksi vanili di Indonesia dengan kualitas yang sesuai dengan permintaan pasar. Tujuan penelitian ini adalah: (1) mengetahui konsentrasi asam fusarat yang efektif untuk menekan jamur $F$. oxysporum f.sp. vanillae dan mengkaji tingkat resistensi planlet vanili dan (2) mengidentifikasi karakter mutan vanili resisten terhadap penyakit busuk batang.

\section{METODE PENELITIAN}

Penelitian ini dilaksanakan di Laboratorium Mikologi Pertanian, Fakultas Pertanian, Universitas Gadjah Mada; Laboratorium Struktur dan Perkembangan Tumbuhan, Fakultas Biologi, Universitas Gadjah Mada, serta Laboratorium Rekayasa Genetika, Pusat Studi Bioteknologi, Universitas Gadjah Mada, mulai April 2011 sampai Maret 2012.

Penyiapan Bahan. Bahan galur murni vanili ( $V$. planifolia Andrews) diperoleh dari unit pelaksana teknis (UPT), Dinas Pertanian, Perkebunan dan Kehutanan, Kabupaten Magelang. Bahan ini sudah dipropagasi secara in vitro dan diseleksi dengan asam fusarat konsentrasi 0 ppm, 90 ppm, 100 ppm, 110 ppm, dan 120 ppm pada penelitian pendahuluan. Isolat jamur $F$. oxysporum f.sp. vanillae, berasal dari perkebunan vanili di daerah Cangkringan, Sleman, Yogyakarta.

\section{Penyiapan Isolat}

a. Isolasi Isolat $\boldsymbol{F}$. oxysporum f.sp. vanilla. Isolasi dilakukan mengikuti metode Hadisutrisno (1995). Batang vanili yang menunjukkan gejala sakit dibersihkan, 
selanjutnya didesinfeksi dengan alkohol $70 \%$. Batang pada batas yang sakit dan sehat diambil secara aseptis dengan scalpel steril, selanjutnya diletakkan di atas medium PDA (Potato Dextrose Agar) dalam cawan petri berdiameter $10 \mathrm{~cm}$. Sayatan batang sakit dalam medium PDA kemudian diinkubasikan pada suhu kamar $\left(25^{\circ} \mathrm{C}\right)$ selama 5-7 hari. Koloni patogen yang tumbuh dipisahkan dari kontaminan sampai diperoleh biakan murni.

b. Isolasi Monospora. Biakan murni yang berumur 2-3 minggu pada medium PDA dalam tabung reaksi ditambah dengan air steril sebanyak $10 \mathrm{ml}$, digojok perlahan-lahan sehingga dihasilkan suspensi konidium. Suspensi konidium ini diambil dengan jarum ose dan digoreskan pada medium PDA dalam cawan petri berdiameter $10 \mathrm{~cm}$ secara zig-zag, kemudian diinkubasikan pada suhu kamar selama 18-20 jam. Satu konidium diambil dan selanjutnya ditumbuhkan dalam cawan petri berdiameter $9 \mathrm{~cm}$ yang berisi medium PDA. Pada setiap cawan petri diletakkan 4 konidia secara terpisah dan diinkubasikan selama 5-7 hari pada suhu kamar $\left(25^{\circ} \mathrm{C}\right)$. Identifikasi varian dilakukan pada hari ke-5 dengan menggunakan kunci identifikasi varian menurut Lahlon dan Basson (1983) yang dimodifikasi menurut Hadisutrisno (1987). Varian yang menunjukkan isolat kuat selanjutnya dipindahkan ke agar miring untuk pengujian selanjutnya (Hadisutrisno, 1995). Semua pengujian dalam penelitian ini menggunakan isolat monospora.

Inokulasi $\boldsymbol{F}$. oxysporum f.sp. vanillae pada Planlet Vanili. Inokulasi dilakukan menurut metode Hadisutrisno (1995). Inokulasi F. oxysporum f.sp. vanillae dilakukan secara langsung pada planlet vanili dalam botol kultur hasil seleksi asam fusarat (konsentrasi 0, 90, 100, dan $110 \mathrm{ppm}$ ), dengan ulangan tiap-tiap perlakuan sebanyak 4 kali. Mikrokonidium jamur $F$. oxysporum f.sp. vanillae dengan kerapatan spora $1,7 \times 10^{4}$ per $\mathrm{ml}$ diteteskan pada planlet 1-2 tetes, kemudian diinkubasikan pada suhu kamar selama 24 jam. Pengamatan dilakukan mulai hari ke tiga setelah inokulasi selama 4 minggu dengan mengamati dan menghitung jumlah daun yang menunjukkan gejala layu atau kuning. Intensitas penyakit dihitung berdasarkan jumlah daun yang menunjukkan gejala daun kuning (layu) dengan indeks kelayuan menurut He et al. (1983 cit. Wibowo, 2002) yang telah dimodifikasi (Tabel 1).

Intensitas penyakit (IP) dihitung dengan rumus:

$$
I P=\frac{\sum(n \times v)}{N \times Z} \times 100 \%
$$

dengan:

IP = Intensitas penyakit

$\mathrm{n}=$ jumlah tanaman pada skor $\mathrm{v}$

$\mathrm{v}=$ nilai skor tertentu

$\mathrm{N}=$ jumlah tanaman yang diuji

$\mathrm{Z}=$ nilai skor tertinggi.

Tingkat ketahanan tanaman ditentukan berdasarkan skoring dengan mengacu pada ketentuan Hanudin (1989 cit. Wibowo, 2002) (Tabel 2).

Karakterisasi Varian atau Mutan Vanili Resisten Penyakit Busuk Batang. Peubah pengamatan meliputi tanggapan kimiawi, tanggapan struktural dan profil protein planlet vanili.

Tabel 1. Indeks kelayuan planlet tanaman vanili

\begin{tabular}{cl}
\hline Skor & \multicolumn{1}{c}{ Keterangan } \\
\hline 0 & Tidak ada gejala kuning (layu) atau tanaman sehat \\
1 & 1-2 daun kuning (layu) \\
2 & 3 daun kuning (layu) \\
3 & 4 daun kuning (layu) \\
4 & Lebih dari 4 daun kuning (layu) atau tanaman mati \\
\hline
\end{tabular}

Tabel 2. Kriteria ketahanan tanaman

\begin{tabular}{cc}
\hline Intensitas Penyakit (IP) $(\%)$ & Kriteria ketahanan \\
\hline$=25$ & Tahan \\
$25<$ IP $=50$ & Moderat \\
$>50$ atau mati & Rentan \\
\hline
\end{tabular}


a. Tanggapan Kimiawi. Berupa pembentukan senyawa fenol total oleh planlet dengan menggunakan analisis fenol total metode Folin-Ciocalteau Micro Method (Waterhouse, 1999). Larutan sampel dibuat menggunakan metode Ozygi et al. (2007), yang telah dimodifikasi. Batang planlet vanili $2 \mathrm{~g}$ (kering angin) diambil lalu dilumat dengan menggunakan mortir gelas dan diekstrak menggunakan $25 \mathrm{ml}$ etanol 80\% (Sigma Chemical Co.) selama $4 \times 24$ jam pada suhu $5{ }^{\circ} \mathrm{C}$. Larutan tersebut kemudian disentrifugasi dengan kecepatan $13.000 \mathrm{rpm}$ selama 15 menit. Supernatan diambil sebanyak $1 \mathrm{ml}$ kemudian ditambahkan $1 \mathrm{ml}$ etanol $80 \%+5 \mathrm{ml}$ akuabides $+250 \mu \mathrm{l}$ pereagen FolinCiocalteu, setelah didiamkan selama 5 menit kemudian ditambah $1 \mathrm{ml} \mathrm{Na}_{2} \mathrm{CO}_{3}$ stok. Larutan sampel kemudian didiamkan pada suhu $20^{\circ} \mathrm{C}$ dalam kondisi gelap selama 1 jam. Larutan sampel dan larutan kalibrasi (standar) di ambil sebanyak $3 \mathrm{ml}$, kemudian dimasukkan dalam kuvet. Setelah itu dilakukan pembacaan serapan dengan spektrofotometer UV-Vis pada panjang gelombang 760 $\mathrm{nm}$. Dasar perhitungan dibuat regresi senyawa fenol total standar, yaitu persamaan regresi antara serapan dengan kepekatan larutan standar.

b. Tanggapan Struktural. Berupa analisis anatomi jaringan yaitu pembentukan lignin pada batang vanili. Pengamatan lignifikasi pada irisan melintang batang vanili yang telah dilakukan pengimbasan asam fusarat dan diinokulasi $F$. oxysporum f.sp. vanillae dengan menggunakan metode Sass (cit. Ruzin, 1999).

Planlet vanili dikeluarkan dari media tanam dalam botol kultur, kemudian dibersihkan batangnya. Batang dipotong lebih kurang $1 \mathrm{~cm}$, lalu difiksasi dengan cara direndam dalam FAA dan disimpan selama 24 jam, selanjutnya dijepit dibagian tengah gabus, dan diiris secara melintang dengan ketebalan 5-10 $\mu \mathrm{m}$ dengan sliding mikrotom. Potongan irisan melintang direndam dalam phloroglucinol 0,5-1,0 gram $+50 \mathrm{ml}$ etanol $95 \%$ selama 15 menit, kemudian direndam dalam larutan $\mathrm{HCl}+$ akuades (1:3) selama 5 menit. Sediaan irisan semipermanen lalu dibubuhi dengan gliserin $87 \%$, dan potongan batang diletakkan di atas gelas preparat dan ditutup dengan gelas penutup. Selanjutnya preparat diamati di bawah mikroskop. Jaringan batang yang terlignifikasi akan tampak berwarna merah-ungu.

c. Profil Protein Planlet Vanili (SDS-PAGE). Untuk mendeteksi protein yang terekspresi, dilakukan dengan cara membandingkan profil protein daun planlet yang diperlakukan dengan asam fusarat dan telah diinokulasi F. oxysporum f.sp. vanillae dibandingkan dengan kontrol. Penentuan profil protein dilakukan dengan metode Sodium Dodecyl Sulphate-Polycrylamide Gel Electrophoresis (SDS-PAGE) menurut Maniatis et al. (1982). Berat Molekul (BM) protein sampel pada setiap jarak migrasi diperoleh dengan cara mengekstrapolasikan setiap jarak pita protein sampel yang dikehendaki pada jarak migrasi 2 pita protein marker yang mengapit pita protein sampel yang dimaksud, sehingga diperoleh log BM, maka BM pita protein yang dimaksud dapat diketahui (Khunsook et al., 2003). Untuk mendeteksi protein spesifik dilakukan dengan cara membandingkan profil protein daun planlet yang resisten terhadap penyakit BBV dibandingkan dengan kontrol.

Analisis Data. Data yang diperoleh dari penelitian ini berupa data kualitatif dan data kuantitatif. Data kualitatif disajikan dalam bentuk deskriptif komparatif dan didukung foto. Data kuantitatif dari setiap parameter seperti jumlah daun kuning (layu), intensitas penyakit ditabulasi dengan faktor konsentrasi yang berbeda dan ulangan 4 eksplan per perlakuan.

Analisis data pada penelitian ini menggunakan Rancangan Acak Lengkap (RAL) faktorial, sedangkan data kuantitatif dari setiap parameter dianalisis dengan Uji F. Apabila ada beda nyata dilanjutkan dengan Uji Jarak Berganda Duncan (UJBD) pada taraf kepercayaan 95\% (Soemartono, 1972).

\section{HASIL DAN PEMBAHASAN}

Isolasi Isolat dan Monospora $F$. oxysporum f.sp. vanillae. Hasil isolasi $F$. oxysporum f.sp. vanillae batang vanili dari kebun vanili di Cangkringan, Sleman menunjukkan variasi warna koloni, pertumbuhan miselium udara, dan kemampuan membentuk konidium. Warna koloni setiap isolat yang ditumbuhkan selama 57 hari bervariasi, dari putih kemerahan sampai keunguan (Gambar 1A), sedangkan koloni yang ditumbuhkan selama 4 minggu berwarna putih (Gambar 1B). Fusarium adalah salah satu jamur yang mempunyai variabilitas tinggi karena sifat genetik dan respon fenotipiknya terhadap perubahan lingkungan (Windels, 1993). Oleh karena itu untuk mendapatkan sifat yang seragam dan stabil dari jamur ini perlu dilakukan isolasi monospora sehingga diperoleh varian yang stabil. Hasil isolasi monospora F. oxysporum f.sp. vanillae berwarna putih dalam medium PDA (Gambar 1C). Monospora inilah yang digunakan untuk pengujian resistensi planlet vanili terhadap penyakit busuk batang. Menurut Salleh (1995), aktivitas pertumbuhan Fusarium sp. terjadi pada kelembaban tinggi, demikian pula Nel et al. (2006) mengemukakan bahwa kisaran suhu untuk pertumbuhan F. oxysporum secara in vitro adalah $25^{\circ}-30{ }^{\circ} \mathrm{C}$. 

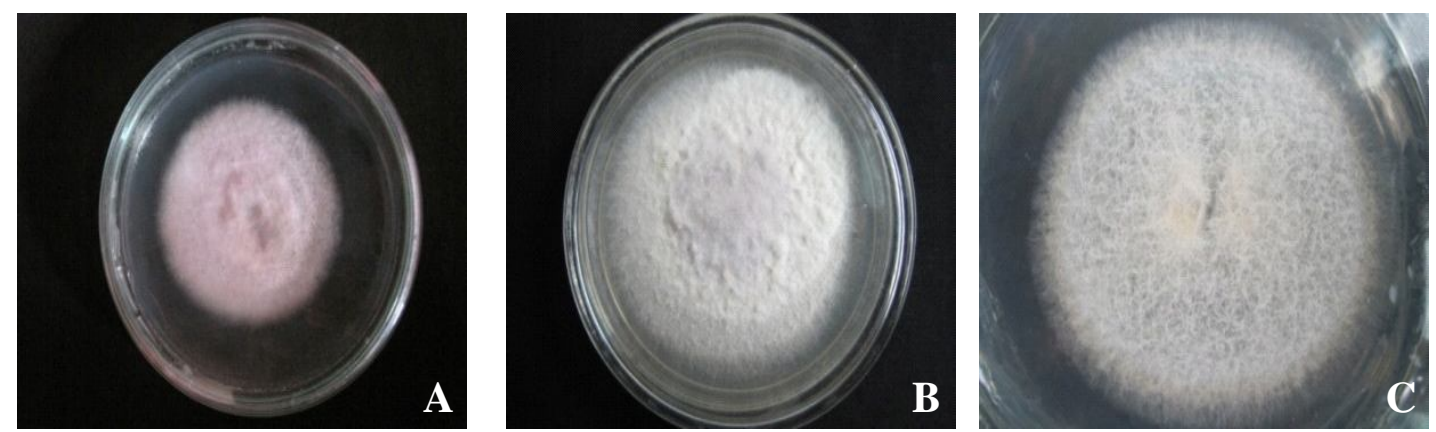

Gambar 1. Koloni F. oxysporum f.sp. vanilla. (A) umur 7 hari, (B) umur 4 minggu dalam medium PDA dan (C) koloni monospora F. oxysporum f.sp. vanillae.

Armstrong dan Armstrong (1981 cit. Soesanto et al., 2003) menyatakan bahwa jamur mempunyai kenampakan secara in vitro berupa miselium udara berwarna putih, yang kemudian akan berubah menjadi warna ungu sampai ungu tua, tergantung dari strainnya. Perbedaan warna koloni dapat terjadi karena kemampuan jamur menghasilkan berbagai metabolit sekunder. Menurut Booth (1971) biakan jamur $F$. oxysporum berwarna merah muda kekuningan, merah kekuningan, atau ungu pada $\mathrm{pH}$ 6,5-7,0.

\section{Inokulasi dan Pengujian Resistensi Planlet Vanili terhadap Fusarium oxysporum f.sp. vanilla. Metode} inokulasi yang digunakan dalam uji ketahanan planlet vanili hasil pengimbasan asam fusarat adalah dengan menginokulasikan secara langsung mikrokonidium jamur F. oxysporum f.sp. vanillae dengan kerapatan spora $1,7 \times 10^{4}$ per ml pada planlet 1-2 tetes di dalam botol kultur secara in vitro, dengan ulangan tiap-tiap perlakuan sebanyak 4 kali kemudian diinkubasikan pada suhu kamar $\left(25{ }^{\circ} \mathrm{C}\right)$ selama 24 jam (Hadisutrisno, 1995). Pengamatan dilakukan setiap hari selama 4 minggu dengan menghitung jumlah daun planlet yang menunjukkan gejala layu.

Berdasarkan pengamatan terhadap planlet vanili yang diimbas, gejala daun layu pada kontrol muncul pada hari ke-5 setelah inokulasi. Gejala daun layu juga muncul pada perlakuan 90 ppm dan 100 ppm kecuali pada botol kultur dengan kode 100-2, namun planlet tersebut pada hari ke-25 muncul gejala daun layu dimulai dari tepi daunnya. Gejala daun layu juga muncul pada perlakuan 110 ppm kecuali pada botol kultur dengan kode 110 -1 dan 110-2. Berdasarkan pengamatan, gejala tersebut menunjukkan gejala penyakit layu Fusarium sehingga nantinya dapat dilakukan perhitungan persentase daun layu atau kuning setiap harinya dan ditentukan kriteria ketahanannya (Tabel 3), sedangkan hasil inokulasi $F$. oxysporum f.sp. vanillae pada planlet vanili umur 29 hari setelah perlakuan dapat dilihat pada Gambar 2.
Tabel 3 menunjukkan bahwa pada hari ke-5 setelah inokulasi persentase daun layu atau kuning pada kontrol telah mencapai rata-rata 31,2\%. Pada perlakuan 90 ppm persentase daun layu atau kuning hampir sama dengan perlakuan $100 \mathrm{ppm}$ yaitu mencapai sekitar $25,0 \%$. Persentase daun layu terendah ditunjukkan pada perlakuan $110 \mathrm{ppm}$ yaitu sebesar $0 \%$, nilai ini tidak berbeda secara nyata dengan kontrol.

Hasil pengamatan hari ke-13 menunjukkan bahwa persentase daun layu atau kuning pada perlakuan 90 ppm meningkat menjadi $41,6 \%$. Peningkatan persentase daun layu atau kuning juga terjadi pada perlakuan 100 ppm yaitu menjadi $31,2 \%$, namun nilai tersebut tidak berbeda nyata dengan kontrol, sedangkan pada perlakuan $110 \mathrm{ppm}$ persentase daun layu atau kuning menjadi $6,2 \%$, nilai ini berbeda secara nyata dengan kontrol. Kenaikan persentase daun layu atau kuning pada pengamatan hari ke-21 terjadi pada kontrol, perlakuan 90 ppm dan 100 ppm (93,7\%; 91,6\%; dan 50,0\%). Sedangkan untuk perlakuan 110 ppm tidak mengalami kenaikan persentase daun layu atau kuning. Persentase daun layu atau kuning pada hari ke-29 setelah inokulasi, pada kontrol meningkat menjadi $100 \%$ dan pada perlakuan 90 ppm terjadi peningkatan menjadi 99,9\%, sedangkan pada perlakuan 100 ppm tidak mengalami kenaikan persentase tetap $50,0 \%$, dan pada perlakuan $110 \mathrm{ppm}$ menjadi $18,7 \%$. Persentase daun layu atau kuning pada perlakuan $100 \mathrm{ppm}$ dan $110 \mathrm{ppm}$ ini berbeda nyata dengan kontrol.

Dari uraian di atas dapat dikatakan bahwa ada pengaruh konsentrasi asam fusarat sebagai bahan pengimbas yang mampu menurunkan persentase daun layu atau kuning pada perlakuan 110 ppm hingga menjadi $18,7 \%$ dibandingkan dengan kontrol. Berdasarkan pengamatan dan uraian di atas dapat dibuat suatu histogram hubungan antara hari pengamatan dan indeks kelayuan (Gambar 3).

Berdasarkan skoring terhadap gejala daun layu atau kuning yang muncul maka dapat diketahui intensitas 
Tabel 3. Persentase daun layu atau kuning pada setiap perlakuan asam fusarat

\begin{tabular}{ccrrrr}
\hline Perlakuan & \multicolumn{5}{c}{ Hari pengamatan } \\
\cline { 2 - 6 }$($ p pm) & 0 & 5 & 13 & 21 & \multicolumn{1}{c}{29} \\
\hline 0 (kontrol) & 0 & $31,25 \mathrm{a}$ & $68,75 \mathrm{~b}$ & $93,75 \mathrm{~b}$ & $100,00 \mathrm{~b}$ \\
90 & 0 & $25,00 \mathrm{a}$ & $41,67 \mathrm{ab}$ & $91,67 \mathrm{~b}$ & $99,99 \mathrm{~b}$ \\
100 & 0 & $24,99 \mathrm{a}$ & $31,25 \mathrm{ab}$ & $50,00 \mathrm{ab}$ & $50,00 \mathrm{a}$ \\
110 & 0 & $0,00 \mathrm{a}$ & $6,25 \mathrm{a}$ & $6,25 \mathrm{a}$ & $18,75 \mathrm{a}$ \\
\hline
\end{tabular}

Angka yang diikuti huruf yang sama pada kolom yang sama tidak berbeda nyata berdasarkan uji Duncan (p>0,05), setelah ditransformasikan akar $\mathrm{x}+1$.
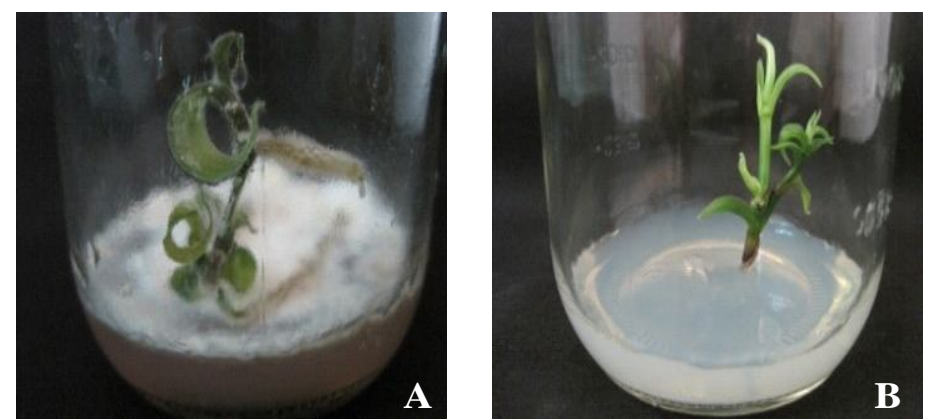

Gambar 2. Hasil inokulasi F. oxysporum f.sp. vanillae pada planlet vanili umur 29 hari setelah perlakuan. (A) planlet vanili kontrol dan (B) planlet vanili hasil pengimbasan asam fusarat $110 \mathrm{ppm}$.

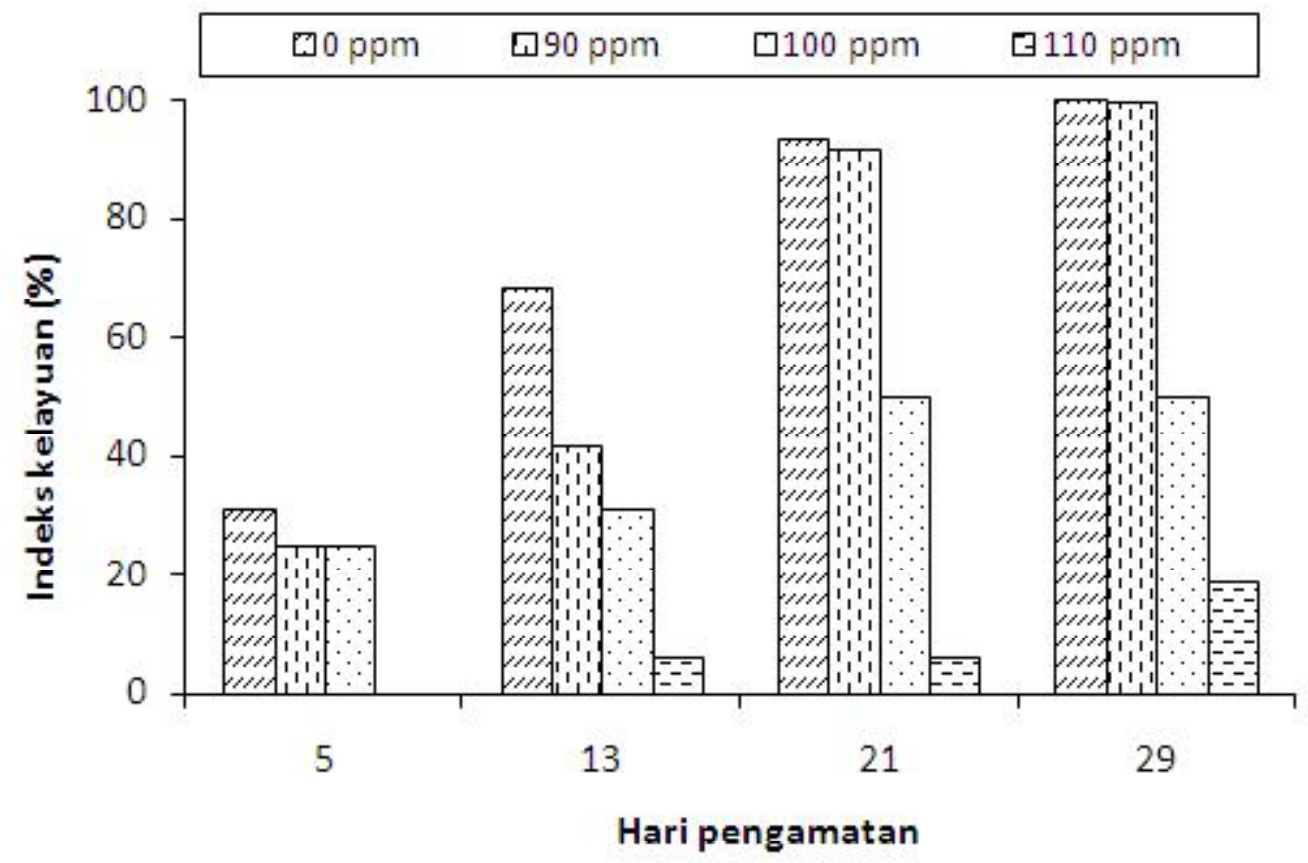

Gambar 3. Histogram hubungan antara hari pengamatan dengan indeks kelayuan (\%) pada hari ke-5, 13, 21, dan 29.

penyakit dari masing-masing perlakuan (Tabel 4). Dari Tabel 4 tersebut dapat dikatakan bahwa pada pengamatan hari ke-29, intensitas penyakit tertinggi ditunjukkan oleh kontrol dan perlakuan 90 ppm (100\%), sehingga dinyatakan rentan terhadap penyakit layu Fusarium, sedangkan perlakuan 100 ppm memiliki intensitas penyakit 50\%, dan kriteria ketahanannya adalah moderat. Pada perlakuan 110 ppm intensitas 
penyakit sebesar 25\% sehingga kriteria ketahanannya adalah tahan. Berdasar hal tersebut dapat diketahui bahwa intensitas penyakit akibat perlakuan $110 \mathrm{ppm}$ asam fusarat tidak mengalami peningkatan sejak pengamatan hari ke-13 hingga hari ke-29. Berdasarkan pengamatan dan uraian di atas dapat dibuat suatu histogram hubungan antara hari pengamatan dan intensitas penyakit (Gambar 4).

Dari data intensitas penyakit dan kategori ketahanannya, dapat diketahui bahwa perlakuan $110 \mathrm{ppm}$ asam fusarat mampu mengimbas ketahanan yang paling baik, sehingga mampu menurunkan nilai intensitas penyakit hingga $25 \%$ dan menaikkan kriteria ketahanan dari moderat menjadi tahan. Hal tersebut menunjukkan bahwa asam fusarat mampu mengimbas ketahanan tanaman vanili terhadap penyakit layu fusarium. Hal ini sesuai dengan pendapat Arai \& Takeuchi (1993) yang menyatakan bahwa toksin murni asam fusarat dan filtrat asam fusarat dapat digunakan sebagai komponen seleksi karena adanya korelasi antara ketahanan terhadap toksin dengan ketahanan terhadap penyakit. Hasil penelitian ini juga mendukung pernyataan Agrios (1997) yang menyatakan bahwa ekspresi dari pengimbasan ketahanan adalah dengan menurunnya intensitas penyakit.

Karakterisasi Mutan Vanili Resisten Penyakit Busuk Batang. Hasil interaksi inang, patogen, ataupun senyawa kimia dapat memberi tanggapan pada tanaman bersifat struktur dan kimiawi yang berbeda (Agrios, 1997).

a. Tanggapan Kimiawi. Berupa pembentukan senyawa fenol total oleh planlet, menggunakan analisis fenol total metode Folin-Ciocalteau Micro Method (Waterhouse, 1999).

Tabel 4. Intensitas penyakit hasil uji ketahanan dan tingkat ketahanan vanili pada setiap perlakuan asam fusarat

\begin{tabular}{|c|c|c|c|c|c|c|c|c|}
\hline \multirow{3}{*}{$\begin{array}{l}\text { Perlakuan } \\
\quad(\mathrm{ppm})\end{array}$} & \multicolumn{8}{|c|}{ Hari pengamatan } \\
\hline & \multicolumn{2}{|r|}{5} & \multicolumn{2}{|r|}{13} & \multicolumn{2}{|r|}{21} & \multicolumn{2}{|r|}{29} \\
\hline & $\begin{array}{l}\text { IP } \\
(\%)\end{array}$ & $\begin{array}{l}\text { Kriteria } \\
\text { Ketahanan }\end{array}$ & $\begin{array}{l}\text { IP } \\
(\%)\end{array}$ & $\begin{array}{l}\text { Kriteria } \\
\text { Ketahanan }\end{array}$ & $\begin{array}{l}\text { IP } \\
(\%)\end{array}$ & $\begin{array}{l}\text { Kriteria } \\
\text { Ketahanan }\end{array}$ & $\begin{array}{l}\text { IP } \\
(\%)\end{array}$ & $\begin{array}{l}\text { Kriteria } \\
\text { Ketahanan }\end{array}$ \\
\hline 0 (kontrol) & 62,50 & Rentan & 91,67 & Rentan & 93,75 & Rentan & 100,00 & Rentan \\
\hline 90 & 66,67 & Rentan & 83,33 & Rentan & 91,67 & Rentan & 100,00 & Rentan \\
\hline 100 & 33,33 & Moderat & 41,67 & Moderat & 50,00 & Moderat & 50,00 & Moderat \\
\hline 110 & 00,00 & Tah an & 25,00 & Tahan & 25,00 & Tahan & 25,00 & Tahan \\
\hline
\end{tabular}

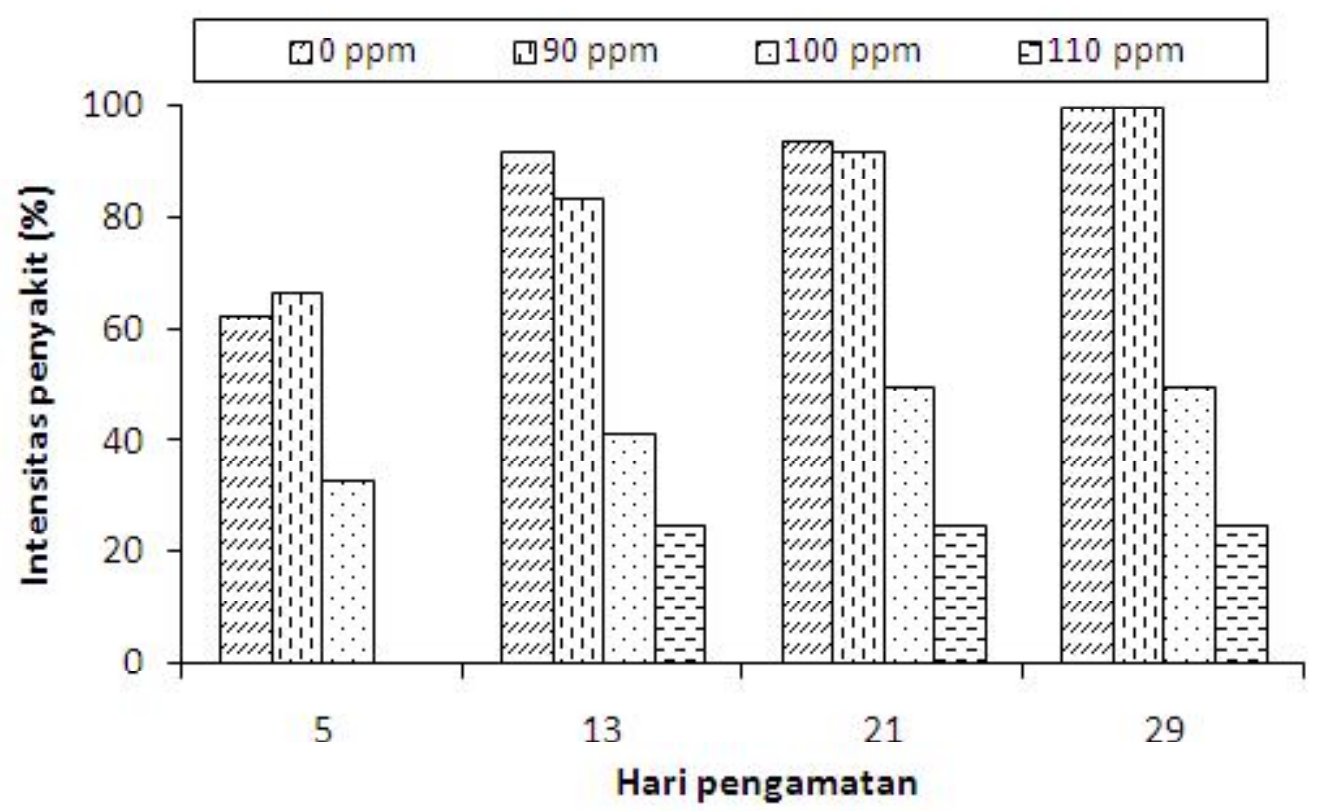

Gambar 4. Histogram hubungan antara hari pengamatan dengan intensitas penyakit (\%) pada hari ke-5, 13, 21, dan 29. 
Pengaruh asam fusarat terhadap pembentukan senyawa fenol pada tanaman vanili dapat dilihat pada Tabel 5. Senyawa fenol merupakan hasil metabolisme tanaman yang terbentuk dengan salah satu fungsi sebagai sistem ketahanan kimiawi tanaman yang mampu mencegah pertumbuhan dan perkembangan patogen.

Konsentrasi senyawa fenol ditemukan pada semua perlakuan asam fusarat. Hasilnya menunjukkan adanya indikasi meningkatnya kandungan total fenol pada daerah dinding sel xilem, yaitu pada perlakuan $90 \mathrm{ppm}$ 5,3\%, 100 ppm 5,5\%, 110 ppm 5,8\% dan kontrol 4,3\%. Semakin tinggi konsentrasi asam fusarat maka semakin meningkat pula kandungan total fenolnya. Pada konsentrasi asam fusarat $110 \mathrm{ppm}$, kandungan fenol total terbesar yaitu $5,87 \%$, dibanding perlakuan konsentrasi asam fusarat yang lain. Hubungan antara konsentrasi asam fusarat dengan kandungan fenol total disajikan dalam bentuk regresi linear (Gambar 5). Peningkatan kandungan fenol total pada tanaman diduga karena terimbas oleh asam fusarat ke dalam jaringan tanaman. Asam fusarat yang digunakan diserap oleh vanili pada saat perlakuan dalam media, kemudian ditranslokasi secara sistemik. Tanaman akan memberikan tanggapan secara kimiawi setelah senyawa tersebut dikenali. Tanggapan inilah yang bertanggungjawab dalam ketahanan terimbas, diantaranya senyawa fenol (Agrios, 1997).

b. Tanggapan Struktural. Berupa pembentukan lignin pada batang vanili. Pengamatan lignin pada irisan melintang batang vanili menggunakan pereaksi phloroglucinol untuk mendeteksinya. Hasil yang diperoleh adalah terbentuknya lapisan lignin yang ditandai dengan adanya perubahan warna merah muda pada jaringan yang mengandung lignin. Hasil pengamatan pada jaringan tanaman menunjukkan bahwa baik pada kontrol maupun perlakuan asam fusarat terbentuk lapisan lignin. Dengan demikian pengaruh perlakuan asam fusarat baru bisa dilihat secara detail antara lain melalui ketebalan ligninnya. Lignin lebih sering terbentuk pada jaringan pengangkutan terutama xylem dibandingkan sel epidermis. Stein et al. 1993 (cit.

Tabel 5. Kandungan fenol total (\%) pada vanili setelah perlakuan dengan asam fusarat

\begin{tabular}{cc}
\hline Perlakuan $(\mathrm{ppm})$ & Rata-rata kandungan fenol total $(\%)$ \\
\hline 0 (kontrol) & $4,39 \pm 0.02$ \\
90 & $5,34 \pm 0.01$ \\
100 & $5,52 \pm 0.02$ \\
110 & $5,87 \pm 0.01$ \\
\hline
\end{tabular}

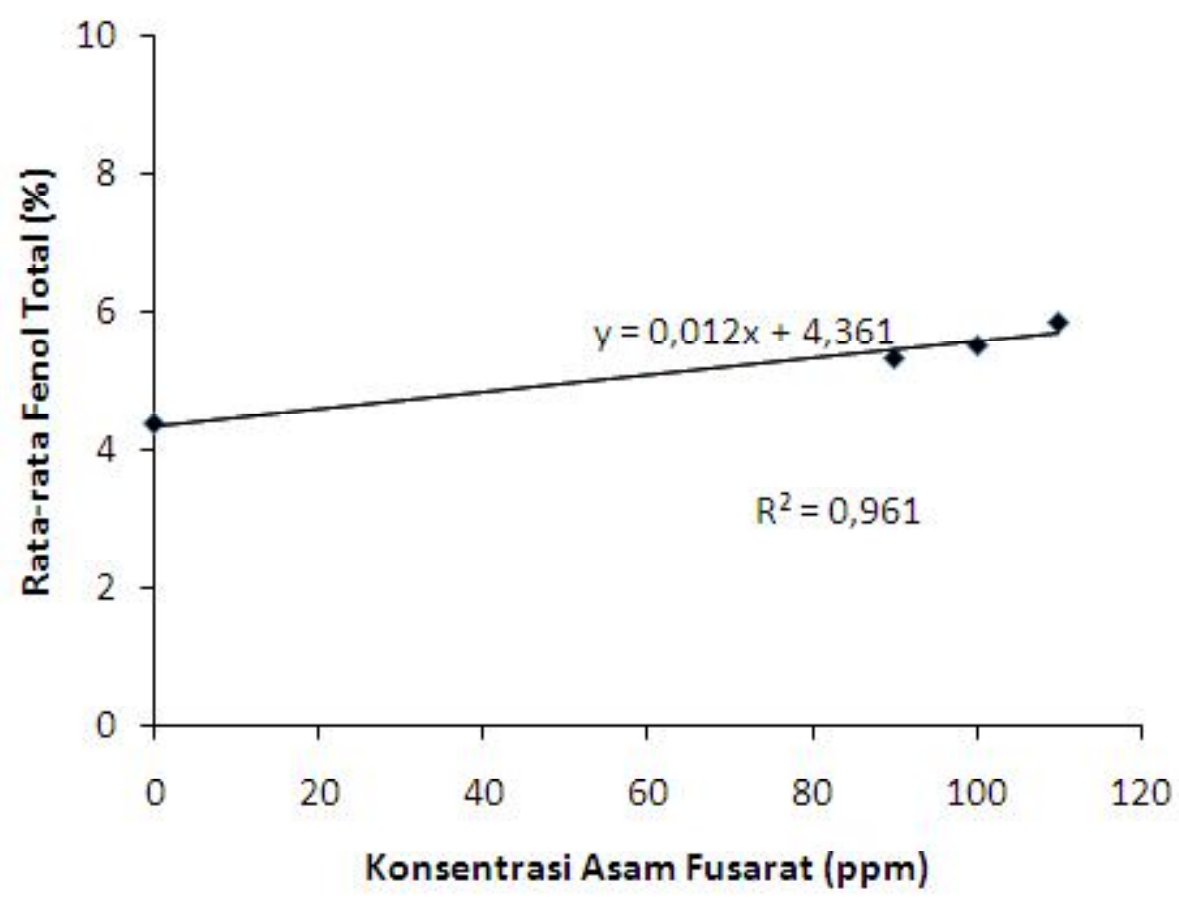

Gambar 5. Garis regresi hubungan antara konsentrasi asam fusarat (pp) dengan fenol total (\%) 
Agrawal et al. 1999), menyatakan bahwa pada fase awal infeksi patogen pada tanaman tahan, lignin atau bahan fenolik lain akan terkumpul pada dinding sel tanaman yang berhubungan dengan patogen. Lignin akan terbentuk dalam jumlah besar dan menghambat perkembangan hifa patogen. Dengan demikian dapat dikatakan bahwa adanya lignifikasi dapat membantu meningkatkan ketahanan tanaman vanili terhadap infeksi fusarium.

Pengaruh konsentrasi asam fusarat terhadap ketebalan lignin vanili dapat dilihat pada Tabel 6. Tabel tersebut menunjukkan adanya indikasi meningkatnya ketebalan lignin pada daerah dinding sel xilem pada

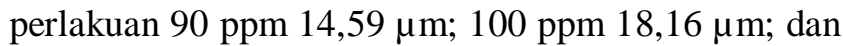
$110 \mathrm{ppm} 19,39 \mu \mathrm{m}$ dibandingkan kontrol $10,28 \mu \mathrm{m}$. Semakin tinggi konsentrasi asam fusarat maka semakin tinggi pula ketebalan ligninnya. Hal ini menunjukkan bahwa vanili memberi tanggapan ketahanan yang lebih baik setelah diperlakukan dengan asam fusarat. Sistem ketahanan tanaman bergantung pada interaksi inang, patogen, dan lingkungan. Lignin merupakan sistem ketahanan struktur tanaman yang berfungsi menghambat patogen dan terbentuk karena adanya tanggapan terhadap penetrasi oleh patogen atau kerusakan yang terjadi secara mekanik (Vance et al. 1980 dan Sticher et al., 1997). Menurut Bouizgarne et al. (2006) dan Kuzniak et al. (1999), penambahan asam fusarat pada konsentrasi non-toksik mengakibatkan peningkatan dan pengaktifan $\mathrm{O}_{2}$ dan $\mathrm{H}_{2} \mathrm{O}_{2}$. Aktivitas $\mathrm{H}_{2} \mathrm{O}_{2}$ berhubungan dengan peroksidase dalam pembentukan lignin. $\mathrm{H}_{2} \mathrm{O}_{2}$ merupakan pendonor peroksidase untuk pembentukan lignin.

\section{c. Pengamatan Profil Protein pada Vanili Hasil Pengimbasan Asam Fusarat dengan Metode} SDS-PAGE. Dalam penelitian ini ditemukan bahwa perlakuan konsentrasi asam fusarat mempengaruhi sintesis protein total daun planlet vanili. Hasil analisis profil protein menggunakan elektroforesis SDS-PAGE vertikal diketahui adanya pita baru pada perlakuan asam

Tabel 6. Pengaruh konsentrasi asam fusarat (ppm) terhadap ketebalan lignin dalam batang vanili

\begin{tabular}{cc}
\hline Perlakuan $(\mathrm{ppm})$ & Rata-rata ketebalan lig nin $(\mu \mathrm{m})$ dengan $\mathrm{n}: 30$ \\
\hline 0 (kontrol) & $10,28 \pm 1,09$ \\
90 & $14,59 \pm 2,38$ \\
100 & $18,16 \pm 2,65$ \\
110 & $19,39 \pm 1,51$ \\
\hline
\end{tabular}

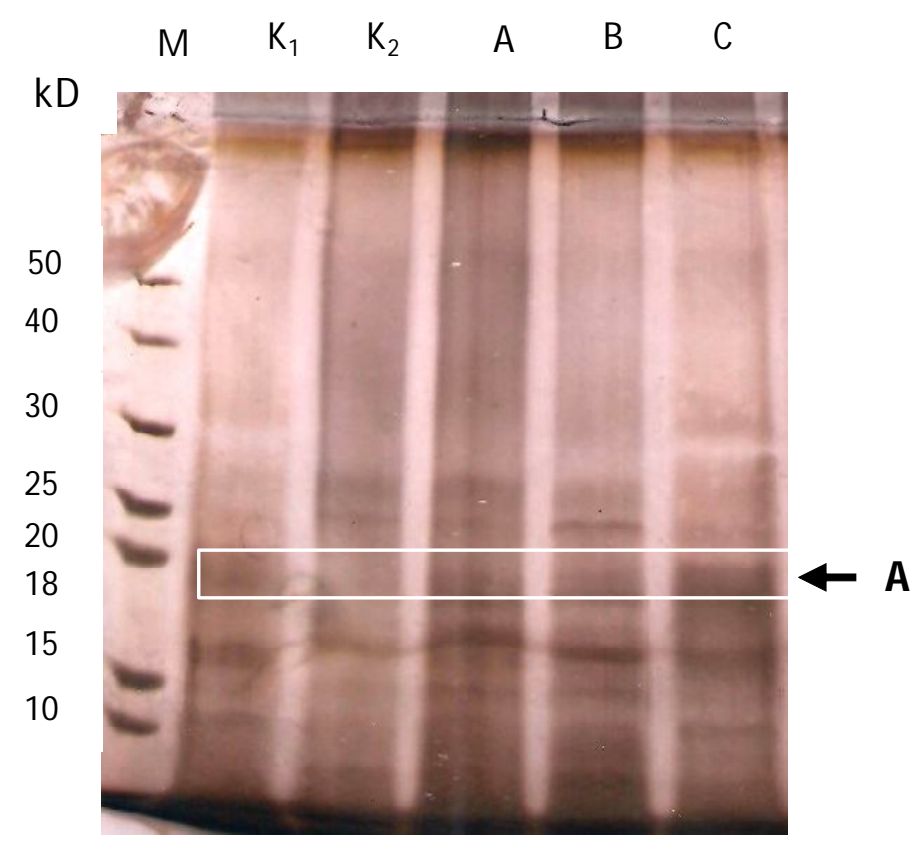

Gambar 5. Profil protein daun planlet Vanilla planifolia Andrews resisten penyakit busuk batang hasil pengimbasan asam fusarat dengan metode SDS-PAGE 1D; (M) Marker, (K1) Kontrol + , (K2) Kontrol - , (A) 90 ppm , (B) $100 \mathrm{ppm}$ dan (C) $110 \mathrm{ppm}$. Tanda panah A= pita protein baru yang terbentuk pada planlet vanili resisten penyakit busuk batang $( \pm 18 \mathrm{kD})$. 
fusarat 90, 100, dan $110 \mathrm{ppm}$ dibandingkan dengan kontrol (Gambar 5).

Perubahan yang terjadi pada tingkat morfologi, anatomi maupun kimia menggambarkan adanya perubahan di tingkat molekuler. Gen membutuhkan waktu dan kondisi yang tepat untuk diekspresikan pada siklus pertumbuhan dan perkembangan tumbuhan. Memasuki suatu tahapan perkembangan baru, tumbuhan membutuhkan ekspresi beberapa gen untuk menghasilkan protein yang berperan dalam setiap reaksi metabolisme dalam sel. Pada perlakuan asam fusarat 90, 100, $110 \mathrm{ppm}$, tampak terbentuk pita protein baru yang tidak terdapat pada tanaman kontrol dan setelah dibandingkan dengan protein standar (marker) diketahui $\mathrm{BM}$ protein tersebut sekitar $18 \mathrm{kD}$. Sintesis protein berukuran sekitar $18 \mathrm{kD}$ ini kemunculannya menyerupai protein antifungal dari biji takana jepang (Brassica juncea var. integrifolia $(18,9 \mathrm{kD})$ yang diteliti oleh Ye \& $\mathrm{Ng}$ (2009). Pita protein baru yang muncul pada planlet vanili dengan perlakuan asam fusarat 90, 100, dan 110 ppm tersebut diprediksi merupakan mutan protein hasil pengimbasan asam fusarat. Untuk membuktikan kebenarannya maka perlu penelitian lebih lanjut.

\section{SIMPULAN}

Penekanan perkembangan jamur $F$. oxysporum f.sp. vanillae menggunakan seleksi asam fusarat pada konsentrasi 110 ppm lebih efektif dibandingkan dengan konsentrasi 90 dan 100 ppm dan mampu menekan intensitas penyakit hingga $25 \%$ serta meningkatkan kriteria ketahanan terhadap penyakit busuk batang dari moderat ke tahan. Semakin meningkat konsentrasi asam fusarat maka meningkat pula kandungan total fenol dan ketebalan lignin di daerah xilem pada vanili resisten penyakit busuk batang. Profil protein pada planlet vanili resisten penyakit busuk batang mengindikasikan adanya pita protein baru $\pm 18 \mathrm{kD}$ yang dihasilkan dari pengimbasan asam fusarat.

\section{SANWACANA}

Sebagian riset ini dibiayai oleh Hibah Penelitian Disertasi Doktor, DIPA Universitas Gadjah Mada, No. Kontrak LPPM-UGM/894/BID.I/2011 tanggal 21 April 2011, dan BPPS DIKTI. Untuk semua itu, penulis mengucapkan banyak terima kasih.

Terima kasih pula penulis ucapkan kepada Unit Pelaksana Teknis (UPT) Dinas Pertanian, Perkebunan dan Kehutanan, Kabupaten Magelang, atas bantuan bibit galur murni Vanilla planifolia Andrews.

\section{DAFTAR PUSTAKA}

Agrawal AA, Tuzun S \& Bent E. 1999. Induced Plant Defenses Againts Phatogens and Herbivores, Biochemistry, Ecology, and Agriculture. APS Press, St. Paul, Minnesota.

Agrios GN. 1997. Plant Pathology. $4^{\text {th }}$ Ed. Academic Press. New York. 922 p.

Arai M \& Takeuchi M. 1993. Influence of Fusarium Wilt toxin(s) on Carnation cell. Plant Cells, Tissue and Organ Culture (34): 287 - 293.

Bacon CW, Porter JK, Norred WP \& Leslie JF. 1996. Production of Fusaric Acid by Fusarium Species. Applied and Environmental Microbiology 62: 4039 - 4043.

Booth C. 1971. The Genus Fusarium. Common. Mycol. Inst. Kew, Surrrey, England.

Borras O, Santos R, Matos AP, Cabral RS \& Arzola M. 2001. A first attempt to use a Fusarium subglutinans culture filtrate for the selection of pinneaplle cultivars resistant to fusariose disease. Plant Breeding 120: 435 - 438.

Bouizgarne B, El-Maarouf Bouteau H, Frankart C, Reboutier D, Madiona K, Pennarun AM, Monestiez M, Trouverie J, Amiar Z, Briand J, Brault M, Rona JP, Ouhdouch Y \& El Hadrami I. 2006. Early physiological responses of Arabidopsis thaliana cells to fusaric acid: Toxic and signallling effects. New Phytopathologist 169: $209-218$.

Hadisutrisno B. 1995. Kajian pengendalian hayati penyakit busuk batang vanili dengan isolat lemah Fusarium batatatis Tucker. Buletin Ilmiah Azolla 21:27-35.

Hadisutrisno B. 2004. Taktik dan strategi perlindungan tanaman menghadapi gangguan penyakit layu Fusarium. Simposium Nasional I. Purwokerto, 2-3 Maret 2004.

Inayati A. 2002. Seleksi Ketahanan Tunas Vanili Terhadap Fusarium oxysporum f.sp. vanillae Secara In Vitro Menggunakan Teknik Doubble Layer, Kultur Filtrat, dan Asam Fusarat. Tesis. (Tidak dipublikasikan).

Khunsook S, Bary SB, Susan RMG \& Jack AA. 2003. Purification and characterization of plasma membrane-associated human spermá-LFocosidase. Biol. Reprod. 709 - 716. 
Kuzniak E, Patykowski J \& Urbanek H. 1999. Involvement of the antioxidative system in tomato responses to fusaric acid treatment. Journal of Phytopathology 147: 385-390.

Landa BB, Cachinero-Diaz JM, Lemanceu P, JimenezDiaz RM \& Alabouvette C. 2002. Effect of fusaric acid and phytoanticipans on growth of rhizobacteria and Fusarium oxysporum. Canadian Journal of Microbiology 48: 971985.

Lestari EG, Sukmadjaja D \& Mariska I. 2006. Perbaikan ketahanan tanaman panili terhadap penyakit layu melalui kultur in vitro. Jurnal Litbang Pertanian: 25(4).

Maniatis T, Fritsch EF \& Sambrook J. 1982. Molecular Cloning. A laboratory manual. Cold Spring Harbor Laboratory, Printed in The United States of America.

Matsumoto K, Luz Barbosa L, Sauoca AC \& Teixeira JB. 1995. Race fusarium wilt tolerance on banana plant selected by fusaric acid. Euphytica 103 : 131-136.

Nel B, Steinberg C, Labuschagne N \& Viljoen A. 2006. Isolation and characterization of nonpathogenic Fusarium oxysporum isolates from the rhizosphere of healthy bananas plants. Plant Pathology 55: 207 - 216.

Ozygi II, Kahraman MV \& Ercan O. 2007). Relation between explant Age, total phenol and regeneration response in tissue cultured cotton (Gossypium hirsutum L.) . African Journal of Biotechnology 6: 3-8.

Pusat Data \& Informasi Pertanian. 2009. Outlook komoditas perkebunan. http://www.deptan.go.id/ $\mathrm{p} \mathrm{u} \mathrm{s} \mathrm{d} \mathrm{a} \mathrm{t} \mathrm{i} \mathrm{n} \mathrm{/} \mathrm{a} \mathrm{d} \mathrm{m} \mathrm{i} \mathrm{n} \mathrm{/} \mathrm{P} \mathrm{U} \mathrm{B} \mathrm{/}$ outlook.komoditas_perkebunan.pdf. Diakses 17 Juni 2010.

Remotti PC \& Löfler HJM. 1996. The Involvement of Fusaric Acid in The Bulb-Rot of Gladiolus. $J$. Phytopathol. 144: 405 - 411.

Remotti PC, Löfler HJM \& Loten-Doting LV. 1997. Selection of cell lines and regeneration of plants resistance to fusaric acid from Gladiolus $\mathrm{x}$ grandiflorus c.v. 'Peter Pear'. Euphytica 96: 237 -245 .

Ruzin SE. 1999. Plant Microtechnique and Microscopy. Oxford University Press. New York.
Salleh B. 1995. Perkembangan Mutakhir Penelitian Fusarium di Kawasan Tropika. Prosiding Kongres Nasional $X$ dan Seminar Ilmiah Perhimpunan Fitopatologi Indonesia, Jakarta.

Soemartono. 1972. Pola Percobaan. Yayasan Pembina Fakultas Pertanian, Universitas Gadjah Mada. Yogyakarta.

Soesanto L, Soedarmono, Prihatiningsih N, Manan A, Iriani E \& Pramono J. 2003. Penyakit busuk rimpang jahe di sentra produksi jahe Jawa Tengah: Identifikasi dan Sebaran. Tropika 11(2): $107-220$.

Sticher L, Mauch-Mani B \& Metraux JP. 1997. Systemic acquired resistance. Annual Review Phytopathology 35: 235-270.

Sukmadjaja D, Mariska I, Lestari EG, Tombe M \& Kosmiatin M. 2003. Pengujian planlet abaka hasil seleksi terhadap F. oxysporum. Prosiding Seminar Hasil Penelitian Rintisan dan Bioteknologi Tanaman. Balai penelitian Bioteknologi dan Sumberdaya Genetik Pertanian, Bogor.

Toyoda H, Hasyashi H \& Yamamoto K. 1984. Selection of resistant tomato calli to fusaric acid. Ann. Phytopathol. Soc. Japan 50: 538 - 540.

Vance CP, Kirk K \& Sherwood RT. 1980. Lignification as a Mechanism of Disease Resistance. Annual Review Phytopathology 18: 259-288.

Wibowo A. 2002. Pengendalian penyakit layu fusarium pada pisang dengan menggunakan Isolat nonpatogenik Fusarium sp. Jurnal Fitopatologi Indonesia Vol. 6: 65-70.

Waterhouse A. 1999. Follin-Ciocalteu Micro method for Total Phenol in Wine. http:// www.waterhouse.ucdavis.edu/phenol/ folinmicro.htm. Diakses 15 Maret 2011.

Windels CE. 1993. Fusarium. pp. 115-128 In: Methods for Research on Soilborne Phytopathogenic fungi. Singleton LL, Mihail JD \& Rush CM. eds. APS Press. St. Paul, Minnesota.

Ye X \& Ng TB. 2009. Isolation and characterization of juncin, an antifungal protein from seeds of Japanese takana (Brassica juncea var. integrifolia). J. Agric. Food Chem. 57(10):4366-71. 